\title{
Debatforum: Dannelsesbegrebet som element i folkehøjskolens selvforståelse
}

\section{Af Kim Arne Pedersen}

Den tyske hermeneutiske filosof H. G. Gadamer har skabt begrebet virkningshistorie som navn for den kæde af fortolkninger, en tekst afstedkommer i historiens løb. For Gadamer skaber teksten tradition, og det er en pointe for ham, at de forskellige fortolkninger, som fremkommer i denne sammenhæng, ikke nødvendigvis er forkerte i forhold til grundteksten, men derimod udfolder en forståelse, der ligger som mulighed i teksten. Dermed siger Gadamer ikke, at enhver fortolkning er lige god. Det er den historisk-kritiske fortolkers opgave at undersøge den "forudforståelse", hun eller han kommer med i kraft af traditionen, holde den sammen med grundteksten eller grundteksterne og $\mathrm{i}$ denne proces både få blik for tekstens fremmedhed $\mathrm{i}$ kraft af nutidens og fortidens forskellige historiske kontekster og for tekstens betydning for nutiden i kraft af dens evne til at fortolke den sammenhæng, fortolkeren står i. Er der virkelig tale om forståelse i kraft af mødet mellem tekst og situation, er det nemlig afgørende, at det ikke primært er fortolkerens greb, der er det vigtige - teksten fortolker derimod sig selv i kraft af fortolkningssituationen, afstedkommet af, at den allerede på forhånd er en del af sammenhængen. Det er vigtigt at forstå, at den nye fortolkning, som fremkommer i denne proces, nok kan være tættere på grundteksten end de forskellige lag af virkningshistorie, som findes i traditionen, men at den derfor ikke er sammenfaldende med en autentisk urforståelse: forståelsens horisonter nærmer sig nok hinanden, men de smelter aldrig sammen, og også hos den videnskabeligt arbejdende historiker er fortolkningen bestemt af hendes eller hans forudforståelse og den erkendelsesinteresse, som giver sig heraf. Gadamers forståelse af fortolkningsprocessen kan benyttes til at sætte historikerens arbejde i perspektiv, når hun eller han står over for en fortolkning af fortiden, der lever som tradition - lever mundtligt med skriftlige nedslag: der er hverken tale om historismens bestræbelser på at komme bag om myterne til en egentlig virkelighed eller om nutidige diskursanalysers fremhævelse af den aktuelle fortolknings anderledeshed $\mathrm{i}$ forhold til tidligere forståelser - og dermed også fremhævelsen af diskontinuiteten i forholdet mellem fortid og nutid - men derimod om myten som en form for forudforståelse, der nok skal korrigeres, men er uomgængelig som grundlag, idet den både traderer udgangspunktet og muliggør den nutidige fortolkers virke - tradererer udgangspunktet, den eller de oprindelige tekster, ved at fremdrage aspekter af disse og rendyrke dem $\mathrm{i}$ en bestemt fortolkningssituation. 
Den danske folkehøjskoles selvforståelse er et eksempel på en fortolkningsproces forstået ud fra Gadamer - der er nye aspekter, der drages frem, men også kontinuitet. Hvor en Gadamer-inspireret fremstilling af forholdet fokuserer på kontinuiteten i udviklingen, peger andre imidlertid på diskontinuiteten. Oplysningshistorikeren Ove Korsgaard arbejder således med forskydninger i højskolens sigte, der afspejler et brud i dens billede af sig selv. I de senere års højskoledebat har begrebet dannelse spillet en central rolle. Højskolens opgave er at bibringe nutidens mennesker dannelse, mens den formelle undervisning sigter mod uddannelse. Sat på spidsen er uddannelse lig med en ensidig instrumentel undervisning $i$ en verden, hvor markedskræfterne er tæt på at måle alt på nytteværdien eller udbyttet, medens dannelse hører hjemme $i$ et helle, et frirum, hvor det alene er muligt at spørge, hvad det vil sige at være menneske - den spørgen, som mange højskolefolk ser som kernen i Grundtvigs berømte lange indledning til Nordens Mythologi fra 1832, et skrift, der altid har spillet en væsentlig rolle i højskolens historie, men efter Anden Verdenskrig har fået næsten absolut status som selve det kanoniske skrift, man tænker ud fra, skriftet, hvori Grundtvig sætter ord på dannelsen som højskolens opgave.

\section{Ove Korsgaards position i højskoledebatten}

Ove Korsgaard fremstår som den skarpsindigste nutidige kritiker af modstillingen dannelse-uddannelse. Korsgaards forskningsbaserede diskussion af højskolens nutidige rolle og muligheder har udspillet sig i sammenhæng med hans forståelse af det sen- eller nu-moderne: individualiseringen og globaliseringen som uomgængelige faktorer, der har løsnet det enkelte menneskes binding til de fortidige fællesskaber og muliggjort sammenhænge på tværs af kontinenter og kulturer, ja, dybest set medført, at en global kultur er lige så afgørende som, ja, vigtigere end den nære kulturelle sammenhæng, det enkelte menneske befinder sig i. I den forbindelse har Korsgaard i Kampen om Lyset fra 1996 peget på nationalismen som den overordnede ideologiske størrelse, Grundtvig fortolkede folkehøjskolen ind i, idet han forstår den grundtvigske universitetstanke som bærer af det universelle, det fællesmenneskelige, i modsætning til folkehøjskolen, der opfattes som bundet til den partikulære nationale sammenhæng og da først og fremmest den aktuelle, øjeblikkelige nationale situation Korsgaard kunne her støtte sig til Grundtvigs ord i Nordens Mythologi 1832 om folkehøjskolens opgave som det at etablere "Dannelse og Duelighed for Livet" (US V, 407), det at tage sigte "paa Folke-Livet for Øieblikket" (US V, 407). Korsgaard har således til en begyndelse talt for at prioritere Grundtvigs universitetstanker frem for den nationalt begrænsede folkehøjskole. I de senere år har han bevæget sig 
frem mod en fokusering på folkehøjskolens forbindelse med den formaliserede uddannelse forstået som livslang læring. I den sammenhæng er begrebsparret ikke primært det nationale og det universelle, men den nationale dannelse/uddannelse kontra den latinbaserede skole, som for Grundtvig var hovedmodstanderen. Bestræbelserne på at svække folkehøjskolens nationale prægning forbindes nu med en fremhævelse af, at den oprindelige folkehøjskole ikke tænkte dannelse og uddannelse fra hinanden. Ove Korsgaard inddrager en række eksempler fra folkehøjskolens historie, som skal godtgøre det nære forhold mellem de to størrelser. På den baggrund argumenterer han for, at folkehøjskolen i dag skal indoptage elementer af formel uddannelse i sit virke, et synspunkt, der har delt mennesker med tilknytning til dagens højskolemiljø. For at diskutere Ove Korsgaards synspunkter er det derfor nødvendigt at tage udgangspunkt i repræsentanter for den nutidige folkehøjskole.

\section{Jørgen Carlsen som reproesentant for folkehøjskolens Grundtvig- reception}

Finn Thorbjørn Hansen, der i sine arbejder tematiserer dannelsesbegrebet, har inddraget folkehøjskolens dannelsesbegreb som en samtalepartner i sin forskning og har her taget udgangspunkt i det dannelsesbegreb, som højskoleforstander Jørgen Carlsen fra Testrup Højskole har formuleret. Jørgen Carlsen opfatter dannelse som værn mod åndløshed. Dannelse er knyttet til "Emner, der grundlæggende får os til at reflektere over og føle os ind på hvad det vil sige at være menneske, hvad meningen er med livet" (Hansen 2000, 235). "Fokus hos Jørgen Carlsen er primært lagt på individet og dets eksistentielle søgen", skriver Finn Thorbjørn Hansen. Det sker dog "ikke ud fra et psykologisk selvrealiseringsparadigme" (ibid., 236), men med sigte på, at menneskets egen stræben nok skal være der i det afgørende øjeblik og føre til

en beundrende undren og træden til siden for noget, der er større end mennesket selv, hvor det så at sige bliver givet en indsigt, (ibid., 237).

Jørgen Carlsen opfatter selv sit dannelsesbegreb som et præcist udtryk for det unikke ved den folkehøjskole, der viderefører den grundtvigske tradition. Centralt i Carlsens tolkning står dannelsesbegrebet, men det fortolkes ud fra to andre begreber, der kan spores tilbage til folkehøjskolens udgangspunkt, åndsbegrebet og frihedsbegrebet sidstnævnte tematiseres ikke, men udgør en implicit forudsætning for, at folkehøjskolen kan være folkehøjskole, i denne er der frihed fra den instrumentalisering af tilværelsen, der i vor tid truer med at blive total. Der er en kulturpessimistisk tendens i Carlsens tænkning, og folkehøjskolen bliver $\mathrm{i}$ hans forståelse et helle eller reservat for sand 
livsoplysning, forudsat den grundtvigske arv fastholdes. ${ }^{1}$ Dannelsesbegrebet, åndsbegrebet og frihedsbegrebet kan således samles $\mathrm{i}$ begrebet livsoplysning, præget af den sene Grundtvig. I den grundtvigske skoleverden bliver ordet "historisk-poetisk" ofte stillet foran ordet "Livsoplysning", noget, Carlsen ikke tematiserer, men som er af afgørende betydning for at forstå begrebet. I første omgang skal der imidlertid fokuseres på de begreber, Carlsen og Grundtvig er fælles om. Foruden Carlsens tekster skal her inddrages elementer fra Carlsens deltagelse i den højskoledebat, der er ført mundtligt i de senere år - et forhold, der er karakteristisk for folkehøjskolen og i sig selv er en tradering af centrale grundtvigske tanker.

Holder man Carlsens forståelse sammen med grundteksterne, i dette tilfælde N. F. S. Grundtvigs skrifter, viser der sig både ligheder og forskelle. En sammenligning rummer her en indlysende fare: opsplitningen af folkehøjskolens arvegods, de grundtvigske tanker, i byggeklodser, som man kan sætte sammen efter forgodtbefindende, eller endnu værre: kanoniseringen af de grundtvigske ideer som en målestok, al nutidig fortolkning måles på, en målestok, der er unddraget tiden og forandringen. Her er det vigtigt at tage udgangspunkt $i$ Gadamers hermeneutik og lade denne åbne blikket for, at nutidige fortolkninger ikke nødvendigvis behøver at være forkerte, selv om de vægter elementer anderledes, end man tidligere har gjort, og at en fortolkning af en fortidig position ikke er stationær, men også inddrager nutidens forståelseshorisont.

Jørgen Carlsens udgangspunkt er åndsbegrebet. I bestemmelsen af dannelse som sigtende mod en beundrende undren ligger en karakteristik af ånd som en form for forholden sig, en menneskets laden sig gribe af livet, som bryder med dets planmæssige, instrumentelle virke, bryder med dets formålsorienterede bestræbelser på at magte livet, at kunne kontrollere det i kraft af de færdigheder, som uddannelsen bibringer det, i nutidig sprogbrug de kompetencer, undervisningen kan give. Der er tale om et afsubstantialiseret åndsbegreb, hvor ånd bliver forstået ud fra en helhedsantropologi og mere bliver lig en ikke-instrumentel forholden sig. Bag Carlsens åndsbegreb "hører" man det 20. århundredes Vilhelm Grønbech-inspirerede livsfilosofi og K. E. Løgstrups eksistentialfænomenologi, måske også den sene Heideggers værensfilosofi. Det er vigtigere at lade sig gribe af livet end at bemestre det, og ånd er lig med denne given sig hen, denne sans for storheden i tilværelsen, som med eller uden Carlsens vilje muliggør en teologisk tolkning af livstydningen, muliggør introduktionen af gudsbegrebet, om ikke andet så som navn på uendelighedsdimensionen $\mathrm{i}$ tilværelsen. Ånd er altså her en forholden sig - men måske også et navn på noget i tilværelsen, der ikke kan skilles fra dennes fysiskmaterielle sider, men heller ikke går restløst op heri, noget, der både er givet mennesket som menneske og rækker ud over det, er navn på det 
"større", Carlsen taler om. Kender man folkehøjskolen og den Grundtvig-reception, der har sat sig igennem siden teologen og højskoleideologen Kaj Thanings virke i 1960'erne, "hører" man bag dette denne receptions forståelse af Grundtvigs åndsbegreb: ånd er ikke noget, der står i modsætning til kroppen, ånd er næsten en fysisk størrelse, eller, for at skærpe forståelsen, noget, der ikke har selvstændig substantiel virkelighed uden om og hinsides den menneskelige tilværelses bundethed til materien, ånd og krop udgør en enhed, og det grundtvigske menneskesyn medfører en afvisning af en dualistisk tilværelsesforståelse.

\title{
Grundtvigs ånds- og dannelsesbegreb
}

Hvordan forholder dette åndsbegreb sig til Grundtvigs? Presser man Jørgen Carlsens åndsbegreb i Finn Thorbjørn Hansens aftapning, kan det forstås som en nutidig fortolkning af Grundtvigs berømte bestemmelse af mennesket i Nordens Mythologi fra 1832, ordene om, at

\begin{abstract}
Mennesket er ingen Abekat, bestemt til først at efterabe de andre Dyr, og siden sig selv til Verdens Ende, men han er en mageløs, underfuld Skabning, i hvem Guddommelige Kræfter skal kundgiøre, udvikle og klare sig giennem tusinde Slægter, som et Guddommeligt Experiment, der viser, hvordan Aand og Støv kan giennemtrænge hinanden, og forklares i en fælles guddommelig Bevidsthed (US V, 408).
\end{abstract}

Her skal begyndes med sammenhængen, kontinuiteten: som Carlsen arbejder Grundtvig med et åndsbegreb, der ikke står i skarp modsætning til kroppen, til det legemlige. Og som Carlsen har Grundtvig blik for, at livet er større end mennesket, for Grundtvigs vedkommende udtrykt i talen om det under- eller gådefulde, i talen om, at man som menneske ikke kan overskue og bemestre tilværelsen. I teksten som helhed bevæger Grundtvig sig mellem individets livsoplysningsproces - "Ja Christen eller Hedning, Tyrk eller Jøde, ethvert Menneske, der bliver sig sin aandelige Natur bevidst, er sig selv en (...) vidunderlig Gaade" (US V, 400) - og menneskeslægtens, og det er en afgørende pointe for ham, at åndsdimensionen udgør det intersubjektive i menneskelivet. Grundtvigs åndsbegreb er udformet i eksplicit modsætning til den forståelse af ånd, som han mødte hos filosoffen Immanuel Kant og i den kantianske tradition. Grundtvig spænder sit menneskesyn op mod det kantianske i den først i vor tid trykte Statsmoessig Oplysning fra 1834 - et skrift, der spiller en væsentlig rolle i Korsgaards Grundtvig-tolkning - og taler om "Selv-Klogskab og SelvRaadighed" og "den hele Gridskhed paa Selv-Stcendighed" (Bugge \& Nielsen 1983, 31) og taler i modsætning dertil om "den aandelige KopSætning (Vaccination)" (ibid., 30) i form af oplysning om det enkelte menneskes fællesskab og sammenhæng med slægten, og menneskeheden knytter til ved erkendeevnerne fantasi og følelse i modsætning 


\section{til fornuften.}

Her er der virkelig basis for den tale om slægtskabet mellem Grundtvig og Løgstrup, der siden 1960'erne har været almindelig: Grundtvig prøver her at tackle og overvinde det kantianske autonomibegreb, og man kan i et vist omfang læse hans forfatterskab som bestemt af modsætningen til den kantianske tradition. Grundtvig er meget bevidst om, at han ikke er idealist i kantiansk forstand, samtidig med, at hans åndsbegreb derfor ikke uden videre kan siges at være uden forbindelser til den platoniske strømning i europæisk tænkning. Men man kan overveje, om Grundtvigs modernitetskritik, hans billede af menneskets myndiggørelse i oplysningens tidsalder som ensidigt bundet til individet, ikke overser Kants tale om det kategoriske imperativs forbundethed med menneskers samliv.

Uanset dette forhold viser en hurtig sammenligning af citaterne fra henholdsvis Carlsen og Grundtvig, at der er elementer i Grundtvigs tænkning, som Carlsen ikke har plads til. Vaccinen mod autonomi og individualisering er for Grundtvig sammenhæng - for Grundtvig er der her primært tænkt på sammenhængen med menneskeslægten forstået som en helhed i bevægelse, på vej mod et mål, menneskeslægtens historie, som det enkelte menneske og det enkelte slægtled indfældes i gennem fantasi og følelse, de erkendeevner, der for Grundtvig udtrykker henholdsvis ånd og krop i mennesket. Grundtvig arbejder nok med et menneskesyn, hvor ånd og krop ikke er absolutte modsætninger, men samtidig er de led i en helhedsforståelse af mennesket, der ikke "går op" i hinanden.

Det grundtvigske åndsbegreb er uhyre komplekst - det spænder over en fortolkning af ånd som den egentlige virkelighed i substantiel forstand - Grundtvig taler om "en virkelig Aande-Verden i det Høie" (US V, 712) - over forståelsen af ånd som "Forestillinger" (ibid., 431) og "Livs-Kraft" (ibid., 712) til den sammenhængs- og fællesskabsdimension, som fremgår af ovenstående citater fra Statsmoessig Oplysning. I bestemmelsen af ånd som kraft og sammenhæng er der tendenser til den afsubstantialisering af åndsbegrebet, som Carlsen gør sig til talsmand for. Trods dette er der tale om forskelle - Grundtvig arbejder med en trichotomisk antropologi, en inddeling af mennesket $i$ ånd, krop og sjæl, og disse tre led - faste og begrebsligt indholdsfyldte størrelser i alt, hvad han skriver - er uløseligt forbundet med en opfattelse af det enkelte menneskes og slægtens liv som en proces, en udvikling. Grundtvigs teleologi, hans opfattelse af, at hele menneskehedens historie sigter mod en afsluttende forståelse, en forklarelse af menneskelivet, bliver i Carlsens optik knyttet til individet, og medens det gådefulde hos Grundtvig er udgangspunktet, der til sidst skal afløses af klarhed, er det hos Carlsen lig med selve dét, menneskets blik skal åbnes for, dét, der udgør kernen i dannelsen.

Grundtvig taler i bevidsthed om den nationale sammenhæng om 
"Folke-Dannelse" (US V, 407) og som påpeget af Korsgaard skelner han mellem denne og "Lærdom" (ibid., 407). Men der er tale om en vekselvirkning mellem disse størrelser eller felter, en vekselvirkning, der står i modsætning til Korsgaards bestræbelser på at skille dem ad, folkehøjskole og universitet skal vekselvirke, videnskabelighedens mål er "Forklaringen af Menneske-Livet" (US V, 414), og Grundtvig sammenfatter den universalhistoriske videnskabelighed således:

Vi staae paa Gravens Bredd, med hele Menneske-Livet bag os, hvis Erfaring vi kan benytte, hvis Forstands-Udbytte vi kan giøre Regning paa; Christendommen byder os en ægte universel Anskuelse af Menneske-Livet i dets Forhold til Himlen og Evigheden, Grækenlands og Nordens Myther afbilde ligesaa universelt Menneskets Forhold til Jorden og Tiden: den Forbigangne, Nærværende og Tilkommende, og Folke-Historierne ligge udbredte for os, saa vi kan see, baade hvad der passer til hvert Sted, og til den nærværende Tid, og vi fattes da aabenbar enten blot Øine til see, Hjerte til at ville, eller Kraft til at udføre, hvad der ligesom paanøder sig os (US V, 442-443).

Den nordiske livsforståelse udgør grobunden for Nyaarstidens universitet $\mathrm{i}$ og med, at den, befrugtet af den græske og hebræiske eller mosaisk-kristelige betragtning af mennesket, er den mest universelle, der gives - når disse tre åndsmagter mødes, sættes den sidste tidsalders bevægelse mod menneskelivets forklaring i værk, den tidsalder, der er Grundtvigs egen, og som han tolker i overensstemmelse med sin grundlæggende optimisme på menneskehedens vegne.

Inddrages Grundtvigs brug af oplysnings- eller dannelsesbegrebet i hans næsten samtidige eller senere tekster ses det, at den principielt universalistisk opfattede livsforståelse eller livstolkning, som ligger i den berømte tekst fra Nordens Mythologi, også er kernen i dette, livsoplysningen sigter mod at åbne ungdommens blik for "Livet, det ædle, virksomme Menneske-Liv" (Grundtvig 1877, 510), om hvilket det enkelte individ får oplysning gennem "Historien, som LivsErfaringen i det store" (ibid., 510). Vekselvirkningen mellem folkedannelsen og lærdommen, hvor universitetet repræsenterer "Menneske-Livets Udvikling og Forklaring i hele Dets gaadefulde Dybde og herlige Mangfoldighed" (GSkv II, 77) medfører, at der ikke er vandtætte skotter mellem de to størrelser - ja, menneskelivet som sådan, det menneskeliv, menneskeheden er fælles om, er kernen også i den nationale oplysning i den folkelige højskoles regi. I den berømte diskussion med Madvig i 1849 taler Grundtvig jo om "en Oplysning og Dannelse, der skal virke velgjørende paa Menneskelivet til i en heel Folkekreds at føles gladere, vise sig ædlere og yttre sig klarere i alle Retninger" (HGS I, 208-209). Grundtvig taler der om "Folkelivet (...), som en Green af Menneskelivets Flod, der har sine egne Enemærker at gjennemkrydse og kvæge" (ibid., 208) og gør det klart, at lærdommen må begynde der - begynde i den partikulære udgave af det universelle 
menneskeliv for så at stige op og overskue hele menneskeslægten.

Dannelsens sigte er livsoplysning, forståelse af menneskelivet, og her deler den sag med lærdommen. Forskellen på folke-dannelse og videnskabelighed er ikke, at folkedannelsen begrænses til en aktuel national kontekst, men at livsoplysningen i folkehøjskolen er knyttet til det nationalt givne, medens universitetet åbner det universelle perspektiv - men samtidig er vekselvirkningen de to imellem så omfattende, at de præger og påvirker hinanden, og de er fælles om sagen. Grundtvig modstiller i Marielyst-talerne et begreb om dannelse, der lader det være ensbetydende med at have "slugt Verdens Viisdom" (Johansen 1956, 62) og det at være klog på "det virkelige MenneskeLiv, især paa den usynlige og indvendige, aandelige og hjertelige Deel deraf" (ibid., 62). Med konstateringen af, at også ulærde kan blive "dannede Mennesker" (ibid., 63) bevæger Grundtvig sig frem til sin hovedtanke, at "ingen kan blive klog paa Menneske-Livet uden ved at leve det" (ibid., 64), det, der danner basis for "en fælles og almindelig Menneske-Dannelse og Oplysning om Menneske-Livet", idet man altså henvender sig til den ungdom, der allerede har et vist kendskab til sig selv indvendig og udvendig. Grundtvig gør det klart, at den "Oplysning", man kan "gøre almindelig", må holde sig til "hvad der kan være fælles for hele vort Folks, altsaa i Danmark, for hele den Danske Ungdom" (ibid., 64). Det for alle mennesker fælles er i Danmark dansk udformet, men folkehøjskolen kan sagtens udstrække perspektivet til det universelle, "saaledes, at den folkelige Høiskole vel kan føre til al menneskelig Oplysning og Dannelse, men maa udgaae fra Folket selv" (ibid., 108), således at den folkelige dannelse også kan blive udgangspunktet for en lærdomskultur, en videnskabelighed.

Lærdomskulturen og den folkelige højskoles dannelse står $\mathrm{i}$ forbindelse med den historisk-poetiske livsoplysning, det at kunne "leve poetisk i en priselig Ihukommelse" (US V, 582), det vil sige at kunne levendegøre fortiden i mindet til inspiration i og fortolkning af nutiden, det forhold, at ånden gennem fantasien som erkendeevne levendegør fortiden $\mathrm{i}$ et billede, at følelsen indoptager dette billede og så at sige giver det en ydre skikkelse og derved muliggør forstandens indoptagelse af og fornuftens refleksion over billedet. Grundtvig skriver:

Har vi saaledes Forestilling om en skiøn Bygning, det være af Kalk eller Steen, af Toner eller Tanker; gjør den et tilsvarende behageligt Indtryk paa os, saa vi lægge Haand paa Værket, og har vi Magt til at fuldføre det, da vil det ligne Forestillingen paa et Haar (US V, 432).

Der er tale om en spiralformet bevægelse, en stadig griben tilbage til åndens forestillinger, en "legemliggørelse" i mere eller mindre konkret betydning af fantasiens billeder, der indgår i den forklaringsproces, Grundtvig skriver frem, og åndsbegrebet står derfor centralt. Og det er her, man kan synliggøre forbindelsen mellem Grundtvigs dannel- 
sesbegreb og hans visioner for samfundet som helhed, herunder næringslivet.

Grundtvig forestillede sig, hans livsforståelse som kernen i dannelsesbegrebet kunne og skulle gennemtrænge hele samfundet, og når Korsgaard i dag peger på sammenhængen mellem dannelse og næringsliv, dannelse og uddannelse, i såvel Grundtvigs højskoletænkning som den folkehøjskole, der voksede frem, har han en god sag. Men han ser bort fra det grundtvigske frihedsbegreb, der er afgørende både på de indre linjer $\mathrm{i}$ folkehøjskolen og $\mathrm{i}$ de grundtvigske samfundstanker som helhed.

\section{Det grundtvigske frihedsbegreb og folkehøjskolen}

Som sagt er der forbindelse mellem Carlsens "beundrende undren" og den fortolkning af Grundtvigs åndsbegreb, man ofte møder, et synspunkt, der frit kan gengives således: "ved ånd forstod Grundtvig ikke noget ulegemligt, ånd var uløseligt forbundet med legemet". Et andet af højskolens "mantraer" har været og er, at Grundtvig ikke er liberalist, men tænker selvstændigt i forhold til liberalisme og socialisme. Det er både rigtigt og forkert - rigtigt, fordi Grundtvigs frihedssyn ikke kan nedskrives til at være en dansk udgave af den engelske liberalisme, forkert, fordi Grundtvig i sin samfundstænkning arbejder med en "svag" stat og med en form for uafhængighed i det, han kalder for folkelivet. Højskolelæreren fra Askov, dr. phil. Holger Kjær har i sin lille bog Frisind eller Tolerance fortolket Grundtvigs samfundssyn i forhold til de frie skoler - først og fremmest den danske friskole, men med en synsvinkel, der omfatter dem alle:

En demokratisk stat er for selve sin eksistens' skyld afhængig af, at der findes selvstændige åndelige kræfter i folket: i kirke, skole og folkeliv, der kan fastholde grænsen over for staten (Kjær 1974, 132).

Holger Kjærs bog er et betydningsfuldt dokument. Her er sat ord på en frihedsforståelse, som i kraft af Kjærs Grundtviglæsning er tæt på udgangspunktet.

Den indre frihed i den folkelige højskole, Grundtvig sigtede imod, var frihed fra eksamen. Et morsomt udtryk for denne frihed i kombination med Grundtvigs tillid til folket finder man i en dialog om højskolen, som først i vore dage er blevet trykt. Grundtvig vågner i Sorø efter en årelang søvn og konstaterer chokeret, at der afholdes eksamen på det folkelige akademi. Hans samtalepartner forklarer ham imidlertid sagens rette sammenhæng, at det ikke er eleverne, der eksamineres:

Nej, det er de gamle Bønder fra Landet, der er kommet ind for at examinere Professorerne og flokkes saa sædvanlig herude Aften og Morgen for at læse Indskrifterne paa Mindes-Mærkerne og snakke om 
Til den indre frihed fra eksaminer lægger sig en ydre frihed fra staten. $\mathrm{Nu}$ er der sikkert flere, der vil indvende, at Grundtvigs folkelige højskole i Soer jo var tænkt oprettet af den danske stat i skikkelse af kongen - fra 1839 Christian VIII til hvem Grundtvig satte sin lid. Men indvendingen holder ikke vand: Grundtvig tænkte sig institutionen fri for lovpligtige eksamener, og han tænkte den ind i den sammenhæng, der fylder hans "nær-eskatologi" ud i 1840'erne, det forhold, at folket nu ville tage over, at staten ville komme til at spille en underordnet rolle som instrument for folket og folkeviljen, i og med, at folket nu i frivillig samdrægtighed ville "Gyldenaaret". Grundtvigs tillid til folket kommer bedst til udtryk i hans tekster omkring tilblivelsen af den danske grundlov. Grundtvig taler om, at vi har:

en Stats-Kirke, et tvungent Skolevcesen, Laugsvæsen og Fattigvæsen, en meget for talrig og begunstiget Embedsstand, en i Længden utaalelig Krigsstand, og i det hele et tomt og dødt Stats-Begreb, der næsten har opslugt det levende Folke-Begreb, at bekæmpe og overvinde, førend en fri og ligelig, en folkelig, altsaa en dansk Tingenes Orden kan blive indført, og Folke-Seieren vindes aabenbar hverken ved Valg-Kampene, eller ved Parti-Kampene paa Rigsdagen, hverken ved den almindelige Stemmeret eller ved de allerordenligste Ordskifter og Afstemninger i Thingene, [Grundtvig er fortaler for det, der er samfundets grundlag, nemlig] Liv, (...) Kraft og (...) Fadernelands-Kicerlighed (Danskeren III, 333-335).

Grundtvigs Gyldenaars-visioner er forbundet med hans tiltro til menneskets frivillige, indre motivation for læring såvel som politisk handling. For Grundtvig var eksamen som belønning direkte vildledende - det gjaldt både menneskets oplæring i næringslivets driftighed og dets dannelse, dets blik for livet, livsoplysningen. Livsnærheden indbefattede for Grundtvig, at der ikke var vandtætte skotter mellem livsoplysningen og livet som landmand, håndværker eller sømand.

Ove Korsgaard har med rette peget på næringslivets og driftighedens betydning i Grundtvigs højskolevision. Grundtvig tænkte afgjort livsoplysning sammen med oplysning af næringslivet - man kunne måske opstille et nyt begrebspar, liv og erhvervsliv - men han tænkte de to størrelser sammen i kontekst af eksamensfrihed, et forhold, der var lige så afgørende som den nationale ramme for folkehøjskoletanken. Det blev afgørende for den grundtvigske folkehøjskole at være eksamensfri - i så høj grad, at det for en så betydelig skikkelse som Jacob Appel kunne blive et problem, at han ikke kunne få lov til at tage en eksamen, et problem, også nulevende mennesker med rod $\mathrm{i}$ det grundtvigske kan fortælle om. ${ }^{2}$ Når folkehøjskolen holdt strengt på udgangspunktet, var den fortaler for en "fri" - det vil sige eksamensfri - uddannelse til højskolelærer, som har udgjort udgangspunktet for mennesker op i nærværende forfatters levetid. Og det er afgørende, at 
man ikke kun her arbejdede med en eksamensfri samordning af dannelse og uddannelse, men også prøvede at udforme egentlige eksamensfri uddannelser, eller i hvert fald uddannelser med en omfattende indre frihed, et forhold, der knap er belyst i forskningen. Men oftest gik man på akkord med den tiltagende eksamensbundne formalisering af uddannelsen i det omgivende samfund. Korsgaard har i sin forskning selv inddraget Vagn Skovgaard-Petersens fremdragelse af den grundtvigske folketingsmand Harald Holms bitre protest mod Venstres realskolelov fra 1904, en protest, der hos Holm er gennemreflekteret og klar, for så vidt som den står i forbindelse med hans opfattelse af Danmark som et agrart samfund, hvor det fysiske arbejde har en fremtrædende placering. Holms tale kan læses som en negativ spådom om det Danmark, der først blev til efter Anden Verdenskrig velfærdssamfundet med uddannelse til alle, hvor en sen industrialisering hurtigt har udviklet sig til det nutidige, post-industrielle samfund, en virkelighed, Holm opfattede som urealistisk og utopisk og derfor tog afstand fra. Holms protest kan ses som den grundtvigske skoleverdens sidste afmægtige forsøg på at tale den frie uddannelses sag. ${ }^{3}$ Når Hal Koch i forbindelse med Anders Pontoppidan Thyssens doktorafhandling om ny-grundtvigianismen erklærede, at det grundtvigske projekt havde lidt nederlag, fremhævede han med rette, at grundtvigske højskolefolk og præster overvejende lod deres børn tage studentereksamen og læse videre på de højere læreanstalter (Koch, 1958). Men samtidig med dette fremholdt man eksamensfriheden som ideal, forbundet med begrebet livsoplysning som folkehøjskolens sigte, og det lykkedes at skabe politisk vilje til, at den eksamensfri folkehøjskole kunne leve i et samfund, hvor den formaliserede uddannelse blev bundet til eksamen som målestok. Der er tale om en meget dansk model - et "både-og", som er i modsætning til Grundtvigs og grundtvigianernes drøm om en fuldstændig omformning af samfundet, men samtidig som virkningshistorie, som de klassiske grundteksters fortolkning ind i skiftende kontekster, også repræsenterer kontinuitet.

\section{Afslutning}

Skolehistorikeren Harry Haue har mundtligt fremhævet, at det unikke ved den grundtvigske folkehøjskoletradition er den eksamensfrie højskole. Frihed er i den grundtvigske skoleverden i det indre lig med frihed fra eksamen og det vil i videre forstand også sige frihed i det ydre fra statens indblanding i skoleforhold, frihed til at holde skole med sigte på dannelsen - og i udgangspositionen i snæver sammenhæng med uddannelsen og næringslivet i Danmark, men afgjort i en eksamensfri konstruktion. Næringslivet synes glemt i nutidens folkehøjskole - men det hører selvsagt med, når man anlægger et helhedsperspektiv på menneskelivet. På mesterlig vis har Korsgaard 
fremdraget dette aspekt, men har han derfor ret i blankt at afvise den nutidige grundtvigske folkehøjskoles selvforståelse? Korsgaard har ikke gjort rede for sine teoretisk-metodiske forudsætninger for sin skarpsindige analyse, men mon ikke den er mere i slægt med en Foucault-inspireret diskursanalyse end en Gadamersk fokusering på traditionen? Diskursanalyse har en tilbøjelighed til at kontrastere diskurserne og fokusere på deres indbyrdes modsætningsforhold. Det ligger lige for at modstille en nutidig og fortidig diskurs. Hermed er der skabt basis for en tilknytning til en almindelig strategi, at skildre fortiden som kritik af nutiden - en strategi, der er i familie med den almindelige grundtvigske tilbøjelighed til at kritisere grundtvigianismen ved hjælp af Grundtvig selv, den strategi, som Thaning rendyrkede i 1960'erne. Den Gadamer-inspirerede indsigt i, at fortiden fortolker nutiden, er i slægt med Grundtvigs pointering af, at den historisk-poetiske livsoplysning implicerer en gentagen fornyelse, at al beskæftigelse med historien sigter mod at lade fortiden genopstå i fornyet skikkelse for at inspirere nutiden til dåd, til den fortolkende udformning af nutiden, der kan ses som legemliggørelse af inspirationen fra fortiden. Og Gadamer har peget på virkningshistoriens positive værdi, på forudforståelsen som forudsætning for en fordybelse i fortiden. Derfor er den nutidige folkehøjskoles arbejde med begrebsparret dannelse-uddannelse måske ikke præcist, men samtidig rummer det en afgørende indsigt. Den højskole, som opstod i takt med Danmarks udvikling fra landbrugssamfund til efterkrigstidens industrination og velfærdsstat med tyngden i byerne, har - selvfølgelig medført en stilisering af de grundtvigske tanker, en tilpasning af arvegodset til den nye kontekst, en opfattelse af folkehøjskolen som et "helle" for en formålsfri, ikke-instrumentaliseret undervisning, der som det er blevet almindeligt at sige i de senere år - sigter mod dannelse og ikke mod uddannelse.

Kan dannelsesaspektet fastholdes uden den markør i uddannelsessystemet, den mulighed, der hedder eksamensfri undervisning? Er den eksamensfri folkehøjskole ikke en legemliggørelse af Grundtvigs visioner om skolen som dannelsesskole? Her tænkes på folkehøjskolen i kontekst af hele den grundtvigske skoleverden, hvor man fortsat finder fortalere for eksamensfrihed i friskolen, og hvor efterskolens klare bevidsthed om, at dens eksaminer ikke er det afgørende, for nærværende forfatter ikke kunne tænkes uden den stadige bevidstgørelse om det livsoplysende sigte, som de to andre grundtvigske skoleformer er talsmænd for. I Gadamers hermeneutik er indbygget en orientering ud fra tekster. Grundtvig er den mundtlige traditions fortaler. Og det er en afgørende pointe for ham, at det åndsbårne ord får en ydre, fysisk skikkelse, at det vekselvirker med det legemlige, ja, selv ligger på grænsen mellem ånd og legeme. Derfor er en ydre, institutionaliseret synliggørelse af den eksamensfri livsoplysning ikke i modsætning til 
det grundtvigske. En sådan institution er bærer af en bestemt frihedsforståelse og er i pagt med Grundtvigs samfundssyn, hvor ikke staten og det statsligt regulerede, men folket er det afgørende.

Folkehøjskolen skal ikke være et reservat for livsoplysning. Reservater har aldrig gavnet beboerne eller det omgivende samfund, og Korsgaard har skarpt og med fuld rette påpeget, at reservatet er $\mathrm{i}$ modstrid med Grundtvigs egen tænken tingene sammen. Implicit i Grundtvigs trichotome antropologi ligger, at det hierarki, som giver sig af, at ånden og det "aandige" ligger øverst, samtidig er tænkt ind i en model, for ånd og legeme vekselvirker. Det har vi brug for $\mathrm{i}$ en tid, hvor det synes, som om de politiske magthavere tager mere hensyn til erhvervsliv og en entydig positiv forståelse af international standard end til de grundtvigske skoletankers dannelsesorientering, og hvor det synes, som om statslig kontrol skal afløse tanken om frihed til folkelige institutioner.

\section{Forkortelser}

Danskeren I-IV: N. F. S. Grundtvig (1848-51), Danskeren. Et Ugeblad, bind 1-4, København; se også $V U$ V, 260-407).

GSkv I-II: K. E. Bugge (1968), Grundtvigs skoleverden i tekster og udkast, bind 1-2, København.

HGS I-III: Ernst J. Borup og Fr. Schrøder (udg.) (1929-31), Haandbog $i$ N. F. S. Grundtvigs Skrifter, bind 1-3, København.

US I-X: Holger Begtrup (udg.) (1904-09), Nik. Fred. Sev. Grundtvigs Udvalgte Skrifter, bind 1-10, København.

$V U$ I-X: Georg Christensen og Hal Koch (udg.) (1940-49), N. F. S. Grundtvigs Varker i Udvalg, bind 1-10, København.

\section{Litteraturliste}

\section{Værker af Grundtvig}

Begtrup, Holger (udg.) (1904-09), Nik. Fred. Sev. Grundtvigs Udvalgte Skrifter, bind 1-10, København.

Borup, Ernst J. og Schrøder, Fr. (udg.) (1929-31), Haandbog i N. F. S. Grundtvigs Skrifter, bind 1-3, København.

Bugge, K. E. (udg.) (1968), Grundtvigs skoleverden i tekster og udkast, bind 1-2, København.

Bugge, K. E. og Nielsen, Vilhelm (udg.) (1983), N. F. S. Grundtvig (1834), Efterskrift til N. F. S. Grundtvig: Statsmassig Oplysning: Et udkast om samfund og skole, København.

Christensen, Georg og Koch, Hal (udg.) (1940-49), N. F. S. Grundtvigs Varker $i$ Udvalg, bind 1-10, København.

Grundtvig, N. F. S. (1832), Nordens Mythologi eller Sindbilledsprog i US V, 376-767. 
— (1837a), “Til Nordmænd om en Norsk Høiskole” i GSkv II, 63-78.

— (1837b), "Academiet i Soer - en sød Drøm” i Dan Ch. Christensen og Susanne Errebo (udg.) (1983), To dialoger om højskolen. Holbæk, 9-22.

- (1848), "Den danske Høiskole, den latinske Minister og Rigsdagsmanden fra Præstø" i HGS I, 205-209.

- (1848-51), Danskeren. Et Ugeblad, bind 1-4, København.

— (1850), "Folke-Vindingen i Danmark ved Omsvinget 1848" i $V U$ $\mathrm{V}, 362-378$.

Grundtvig, Stener (udg.) (1877), N. F. S. Grundtvig's Mands Minde 1788-1838. Foredrag over det sidste halve Aarhundredes Historie holdte 1838, København.

Johansen, Steen (udg.) (1956), N. F. S. Grundtvig, Taler paa Marielyst Højskole 1856-71, København.

\section{Værker af andre forfattere}

Carlsen, Jørgen (2004), "Rend mig i kompetencerne!" Kronik i Berlingske Tidende 15. april 2004.

Grundvig, Stener (1920), N. F. S. Grundtvigs Englandsbreve til hans Hustru. Udgivne af deres Børnebørn, København.

Hansen, Finn Thorbjørn (2000), Den sokratiske dialoggruppe. Et varktøj til vardiafklaring, København.

Harald Holm (1902), "1. Beh. af Lovf. om højere Almenskoler m.m.", Folketingstidende 29. Oct. 1902, 741.

Kjær, Holger (1974), Frisind eller Tolerance, - et enten eller, Fredericia.

Koch, Hal (1958), “Anmeldelse af: Anders Pontoppidan Thyssen: Den nygrundtvigske bevægelse". Kronik i Politiken 27. marts 1958.

Korsgaard, Ove (1997), Kampen om lyset. Dansk voksenoplysning gennem 500 år, København.

(2004), Kampen om folket. Et dannelsesperspektiv på dansk historie gennem 500 år, København.

Noter

J. Carlsen modstiller her dannelsesbegrebet og kompetencebegrebet, se Carlsen 2004.

2 Allerede for Grundtvigs sønner blev dette et problem. Barnebarnet Stener Grundtvig fortæller, hvordan Grundtvigs hustru sikrede deres studentereksamen: "Deres Moder forstod imidlertid, at Grundtvigs Tanker ved denne Opdragelsesmethode ikke vare af denne Verden, og ved hendes Hjælp - den han aldrig glemte - lykkedes det da ogsaa Johan (...) 20 Aar gammel at tage Artium" (Grundtvig 1920, Indledning, XII).

3 "Det er jo en bekendt Sag, at med Hensyn til vort Skolevæsens Ordning, staa Socialdemokratiet og vort gamle Høire i det væsentlige paa samme 
Grund. Der kan være Forskel i Detaljerne, men med Hensyn til selve Spørgsmaalet om Forbindelsen mellem de forskellige Arter af Skoler, have de to Partier altid haft den samme Opfattelse. De have haft samme Mening om Undervisningens Maal. Hvad der er mere mærkeligt, er, at det ser ud, som om nu ogsaa hele Venstre med Undtagelse af ganske enkelte som mig og saadanne enligtstaaende Personer, der have en anden Opfattelse, er enigt om det samme. Det er imidlertid ikke fuldt saa mærkeligt, som det ser ud til. Thi naar vi se paa, hvorledes Forholdene have udviklet sig, maa vi erindre, at der her i Danmark har været to Slags Venstre - og det er der den Dag i Dag - med Hensyn til Behandlingen af Skolespørgsmaal. Der har altid inden for Venstre været to Retninger: en, som har haft sit Midtpunkt i den Dannelse, der udgik fra Folkeskolen og Folkehøjskolen, og en anden, der har sit Midtpunkt i den Opfattelse, der rører sig i Studenterkredse, bl.a. i Studentersamfundet. Lige fra Begyndelsen af Firserne til den sidste Tid har det været den Del af Venstre, der mener, vi skulle bygge den almene Folkeoplysning paa Folkeskolen og Folkehøjskolen, som har ført an med Hensyn til Behandlingen af Skolespørgsmaal. Men dette er nu forandret, idet den Del af Venstre, som nu fører an med Hensyn til Skolespørgsmaal, er Mændene fra 70erne. Det er den gamle Skoles og Studentersamfundets Mænd" (Holm 1902, 741).

"I Rigsdagen synes det, at den gammeldags Opfattelse af Skolens Formaal i det væsentlige har sejret i den Opfattelse, at Skolens Opgave er at føre fremad til højere og højere Eksamener, til flere og flere Fag, særlig til flere og flere Sprog, overhovedet til en større og større Kundskabsmængde (...) Det er blevet sagt i den Diskussion, som jeg i Foraaret havde med det ærede Medlem fra Frederiksberg ved Skolemødet i Varde, at det virkelig ogsaa maatte være Idealet, hvis det var muligt, at alle Mennesker, saa vidt de havde Evner dertil, naaede frem til Studentereksamen i 18 Aars Alderen. Saa kunde de derefter tage fat i det praktiske Liv og bestemme, om de vilde være Tømmermænd, Landboere eller hvad andet de vilde være (...) Jeg tilstaar frit, det er ikke mit Ideal. Jeg tror for det første, det er et ganske umuligt Ideal, jeg tror slet ikke, at Staten vilde kunne overkomme at naa det; det vilde overstige alle vore $ø$ øonomiske Kræfter (...) hvis man naaede det, vilde jeg for min Deel betragte det som en Landsulykke, idet jeg vil tro, vi paa den Maade vilde faa vort Folk ganske afvænt med det virkelige Livs Arbejde" (ibid. 743). Se hertil Korsgaard 2004, 380). 